\title{
Model-based analyses reveal insular population diversification and cryptic frog species in the Ischnocnema parva complex in the Atlantic forest of Brazil
}

\author{
Marcelo Gehara ${ }^{\mathrm{a}, \mathrm{b}, *}$, Adriane Barth ${ }^{\mathrm{b}, \mathrm{c}, \mathrm{d}}$, Eliana Faria de Oliveira ${ }^{\mathrm{e}}$, Marco Antonio Costa ${ }^{\mathrm{d}}$, \\ Célio Fernando Baptista Haddad ${ }^{\mathrm{f}}$, Miguel Vences ${ }^{\mathrm{b}}$ \\ ${ }^{a}$ American Museum of Natural History, Herpetology, Central Park West at 79th St., New York, NY 10024, USA \\ ${ }^{\mathrm{b}}$ Zoological Institute, Division of Evolutionary Biology University of Technology of Braunschweig, Mendelssohnstr. 4, 38106 Braunschweig, Germany \\ ${ }^{\mathrm{c}}$ Departamento de Ensino Instituto Federal de Educação, Ciência e Tecnologia de Mato Grosso - IFMT, Rondonópolis, Mato Grosso 78721-520, Brazil \\ ${ }^{\mathrm{d}}$ Universidade Estadual de Santa Cruz, Departamento de Ciências Biológicas Ilhéus, Bahia 45662-900, Brazil \\ e Universidade Federal de Mato Grosso do Sul, Centro de Ciências Biológicas e da Saúde, Laboratório de Zoologia, Cidade Universitária, Campo Grande, Mato Grosso do Sul \\ 79002-970, Brazil \\ ${ }^{\mathrm{f}}$ Universidade Estadual Paulista (UNESP), Departamento de Zoologia, Instituto de Biociências and Centro de Aquicultura (CAUNESP), Campus Rio Claro, 13506-900 Rio Claro, \\ São Paulo, Brazil
}

\section{A R T I C L E I N F O}

\section{Article history:}

Received 27 September 2016

Revised 29 March 2017

Accepted 7 April 2017

Available online 9 April 2017

\section{Keywords:}

Amphibia

Brachycephalidae

Cryptic diversity

Species delimitation

Insular diversification

$\mathrm{ABC}$

\begin{abstract}
A B S T R A C T
The Atlantic Forest (AF) of Brazil has long been recognized as a biodiversity conservation hotspot. Despite decades of studies the species inventory of this biome continues to increase with the discovery of cryptic diversity and the description of new species. Different diversification mechanisms have been proposed to explain the diversity in the region, including models of forest dynamics, barriers to gene flow and dispersal. Also, sea level change is thought to have influenced coastal diversification and isolated populations on continental islands. However, the timing and mode of diversification of insular populations in the AF region were rarely investigated. Here, we analyze the phylogeography and species diversity of the small-sized direct-developing frog Ischnocnema parva. These frogs are independent from water bodies but dependent on forest cover and high humidity, and provide good models to understand forest dynamics and insular diversification. Our analysis was based on DNA sequences for one mitochondrial and four nuclear genes of 71 samples from 18 localities including two islands, São Sebastião, municipality of Ilhabela, and Mar Virado, municipality of Ubatuba, both in the state of São Paulo. We use molecular taxonomic methods to show that I. parva is composed of six independently evolving lineages, with the nominal I. parva likely endemic to the type locality. The time-calibrated species tree shows that these lineages have diverged in the Pliocene and Pleistocene, suggesting the persistence of micro-refuges of forest in the AF. For the two insular populations we used approximate Bayesian computation to test different diversification hypotheses. Our findings support isolation with migration for São Sebastião population, with $\sim 1$ Mya divergence time, and isolation without migration for Mar Virado population, with $\sim 13$ Kya divergence time, suggesting a combination of different processes for diversification on AF islands.
\end{abstract}

(c) 2017 Published by Elsevier Inc.

\section{Introduction}

The Atlantic Forest (AF) of Brazil has long been recognized as a biodiversity conservation hotspot given the threat its last remnants are experiencing, its high species diversity, and the high degree of endemism of its fauna and flora (Myers et al., 2000).

\footnotetext{
* Corresponding author at: American Museum of Natural History, Herpetology, Central Park West at 79th St., New York, NY 10024, USA.

E-mail address: marcelo.gehara@gmail.com (M. Gehara).
}

Given its relatively simple geography, with a rather linear northsouth extension along a latitudinal gradient, the AF has also served to develop models of species diversification (Carnaval et al., 2009; Martins, 2011). Hypotheses of diversification mechanisms for AF rely mostly on allopatric models. These models invoke the role of riverine and geomorphological barriers (Wallace, 1852; Pellegrino et al., 2005; Thomé et al., 2014), or the role of Quaternary climatic oscillations on population isolation (Haffer, 1969; Vanzolini and Williams, 1981; Carnaval and Moritz, 2008; d'Horta et al., 2011). Models that rely on dispersal suggest pro- 
cesses of faunal exchange between AF and Amazon (Costa, 2003; Batalha-Filho et al., 2013). These explanations are not mutually exclusive and might also act in combination, resulting in complex evolutionary scenarios (Costa, 2003; Grazziotin et al., 2006).

Regardless of which diversification mechanisms are acting on the AF, they certainly generated high levels of diversity. Considering the amphibians, the biome harbors approximately 550 species (Haddad et al., 2013). The AF also seems to hold higher amphibian within-species genetic diversity in comparison to open areas, a pattern that is shared with two other tropical regions, Cuba and Madagascar (Rodríguez et al., 2015). Despite several decades of intensive studies on the AF, new species are still regularly discovered and named, while other well-established species are recognized as species complexes containing numerous candidate species that await formal description (Santana et al., 2012; Gehara et al., 2013, 2014; Condez et al., 2014; Lourenço-deMoraes et al., 2014; Tonini et al., 2014; Ribeiro et al., 2015). This trend agrees with results from many other regions of the world where a routine application of molecular screening uncovers unprecedented levels of genetic diversity of amphibians, and integrative and molecular approaches lead to ever increasing rates of species description (Meegaskumbura et al., 2002; Stuart et al., 2006; Fouquet et al., 2007a, 2007b; Vieites et al., 2009; Funk et al., 2012; Rowley et al., 2015).

Because the AF extends along Brazil's coast, the evolutionary history of its biota has also been influenced by sea-level changes that often led to the isolation of populations on continental islands. Diversification of some mainland lineages of AF amphibians was likely influenced by marine introgressions (Fitzpatrick et al., 2009; Bell et al., 2012). It has been suggested that cyclical sealevel changes influenced diversity and generated high endemism of freshwater fishes (Thomaz et al., 2015). Also, this process is thought to have triggered vicariant speciation of endemic island taxa. One extreme case is the rodent Cavia intermedia, a species endemic to one island of Moleques do Sul archipelago, in the state of Santa Catarina. The species has a very small habitat (9.86 ha) and an estimated population of around 40 individuals (Salvador and Fernandez, 2008). Other examples are two snakes of the Bothrops jararaca complex, Bothrops alcatraz and Bothrops insularis, which are endemic to two different islands of São Paulo State, Alcatrazes and Queimada Grande, respectively (Grazziotin et al., 2006). Those two islands were connected to the continent by a land bridge during the Last Glacial Maximum (LGM) (Fleming et al., 1998; Suguio et al., 2005), and they also harbor endemic species of hylid frogs of the Scinax perpusillus group (Brasileiro et al., 2007a, 2007c). However, in both cases (Scinax and Bothrops), despite the evident morphological differences found between mainland and island species, genetic differences are very low (see Grazziotin et al., 2006; Bell et al., 2012). Conversely, for frogs of the Thoropa miliaris species complex, mitochondrial genes are sorted in some continental islands of the coast of São Paulo State, but there is a lack of clear morphological differentiation (Fitzpatrick et al., 2009). The studies above indicate the possibility of isolation of island populations before the LGM, but also after the LGM, and the process through which they diversified remains unknown. Are these diversifications on islands consistent with isolation without gene flow after the LGM? Or do they reflect older isolation, maybe combined with exchanges of migrants among the continent and the islands during glaciation events?

In this study we focus on the small leaf-litter frog, Ischnocnema parva, to investigate diversification processes in the coast of AF. The species, as currently understood, is distributed in the southeastern AF, along the Serra do Mar corridor, Serra da Mantiqueira massifs and surroundings, as well as in continental islands, comprehending the states of Rio de Janeiro (RJ), São Paulo (SP), Minas Gerais (MG), and Espírito Santo (ES). Their independence from water bodies and their dependence on humid forests make them good models to understand forest dynamics and insular diversification in the AF. Additionally, the presence of cryptic diversity in the genus Ischnocnema is suggested by recent taxonomic reviews (Canedo and Haddad, 2012; Brusquetti et al., 2013). The genus belongs to the direct-developing frogs in the family Brachycephalidae (Padial et al., 2014), a Neotropical group known to contain a large number of morphologically similar anuran species (e.g. Gehara et al., 2013).

To clarify the diversification of I. parva, we generated DNA sequences of one mitochondrial and four nuclear genes from samples across the range of the species, including the type locality and two continental islands. We then used model-based molecular taxonomy to identify independently evolving populations and to elaborate hypotheses on the taxonomic status of the species (see Fujita et al., 2012). We subsequently used approximate Bayesian computation $(A B C)$ to test three hypotheses of diversification on islands here defined as: Post-glacial isolation (PostLGM-IS), Pre-glacial isolation (PreLGM-IS), and Pre-glacial isolation with migration (PreLGM-IM). The PostLGM-IS hypothesis represents diversification where insular populations got isolated after the LGM and there was no gene flow since isolation. The PreLGM-IS hypothesis assumes an older isolation before the LGM, and the PreLGM-IM represents the same older diversification, but with gene flow between mainland and island. Our results contribute to the understanding of AF biodiversity by finding new undescribed species and by bringing new insights on forest stability and insular diversification mechanisms along the AF coast.

\section{Material and methods}

\subsection{Data collection}

The focal species of this study, Ischnocnema parva, is locally abundant. It is mostly found on leaf litter in rainforest, feeds on a variety of small arthropods, and lays 22-40 eggs (Martins et al., 2010). Calling activity is continuous over the year (Bertoluci and Rodrigues, 2002) and occurs in the late afternoon and at night (Heyer et al., 1990). Mean body size is $13 \mathrm{~mm}$ in males and $19 \mathrm{~mm}$ in females (Martins et al., 2010). We analyzed samples of 71 individuals of this species that were collected during various field expeditions from 18 localities in São Paulo and Rio de Janeiro States in Brazil (Fig. S1; see Table S1 for a full list of samples and the corresponding detailed map). Specimens and tissues are deposited in Célio F. B. Haddad collection (CFBH), Departamento de Zoologia, I.B., UNESP, Rio Claro, SP, Brazil, or in the herpetological collection of Museu Nacional - UFRJ (MNRJ).

We extracted total genomic DNA from leg muscle using a standard salt extraction protocol (Bruford et al., 1992). Sequences of segments of the mitochondrial gene 16S rRNA (16S) and of the nuclear genes Histone 3 (H3), proopiomelanocortin (POMC), recombination activating gene 1 (RAG1) and Tyrosinase (Tyr) were amplified using PCR (for details see 'PRC protocol' in Appendix S1 and Table S2 in Supplementary material) and directly sequenced on a capillary sequencer (ABI 3130XL). All newly determined sequences were submitted to GenBank (see Table S1 for accession numbers).

Sequences were checked and trimmed using CodonCode Aligner 3.7.1 (CodonCode Corporation, Dedham, MA, USA). We assumed heterozygosity for nuclear sequences when the sequences of the chromatogram contained strong equal double peaks, typically of $50 \%$ the height of neighboring homozygotic peaks. Subsequently, we aligned sequences using the ClustalW algorithm implemented in the software MEGA 5.0 (Tamura et al., 2011) and adjusted them manually. We found indels in the $16 \mathrm{~S}$ alignment and removed 
them using GBLOCKS 0.91b (Castresana, 2000; Talavera and Castresana, 2007), available as a web server (http://molevol. cmima.csic.es/castresana/Gblocks_server.html). We used the default options and parameter values in GBLOCKS: number of sequences for a conserved position (36), minimum number of sequences for a flanking position (60), maximum number of contiguous nonconserved positions (eight), minimum length of a block (10), and allowed gap positions (none). The nuclear sequences were phased by the PHASE algorithm (Stephens et al., 2001) using the program DNAsp 5 (Librado and Rozas, 2009). To estimate the best substitution model of each gene segment (Table S3) we used the Bayesian Information Criterion (BIC, Sullivan and Joyce, 2005) implemented in jModelTest 2.1.4 (Darriba et al., 2012).

\subsection{Gene trees and haplotype networks}

We estimated gene trees independently for mitochondrial and nuclear genes using Bayesian inference in BEAST 1.8.0 software (Drummond et al., 2012). To evaluate whether all the samples included in the dataset form a monophyletic group representing Ischnocnema parva, we included I. holti, I. guentheri, I. verrucosa and I. nanahallux as outgroups in the $16 S$ tree. We used the most appropriate substitution model for each gene (Table S3) and ran $20,000,000$ generations sampled every 2,000 generations, yielding five gene trees. We visually assessed convergence of the MCMC runs and effective sample sizes (ESS values $\geq 200$ ) using TRACER 1.5 (Rambaut and Drummond, 2009). We discarded 10\% of generations as burn-in, and the consensus tree for each locus was inferred with Tree Annotator 1.8. We used these gene trees (without outgroups) to estimate haplotype networks in HAPLOVIEWER (http://www.cibiv.at/ greg/haploviewer). Individuals were assigned to populations following BPP results (see Section 2.3). Additionally, for the lineage SP1 (see Section 3), which contains insular populations, we generated separate haplotype networks following the same protocol to inspect the level of haplotype sharing between island and mainland.

\subsection{Population assignment and species delimitation}

To identify genetic breaks in our dataset we performed two analyses: (i) a population assignment test using STRUCTURE v2.2 (Pritchard et al., 2000) and (ii) the Bayesian implementation of the Generalized mixed Yule-coalescent species delimitation method (bGMYC) (Reid and Carstens, 2012; Fujisawa and Barraclough, 2013). For the STRUCTURE analysis, in order to take advantage of the entire information content of the sequence data, we used as input a genotype matrix of all nuclear loci, which was generated following Falush et al. (2003). To identify the number of populations, we ran a series of analyses with different numbers of clusters ( $K$; from 1 to 12 ). We assumed a linkage model with correlated allele frequencies and ran the analyses for 100,000 generations after a burn-in period of 100,000 generations. We calculated the number of populations $(K)$ according to Evanno et al. (2005) using StructureHarvester v0.6.9 (Earl and vonHoldt, 2012). STRUCTURE assigns individuals into populations based on Hardy-Weinberg equilibrium, an assumption often violated by the type of data used here. Also, it does not perform well when sample size is uneven (Puechmaille, 2016). Therefore, we used the bGMYC species-delimitation method on our $16 \mathrm{~S}$ data as an alternative approach to delimit populations. The bGMYC is a coalescent-based method to delimit species accounting for topological uncertainty. We selected the bGMYC inputs by randomly sampling, after a $20 \%$ burn-in, 100 trees from the population of 10,000 gene trees estimated in the BEAST analysis (see Section 2.2). For each tree we ran an MCMC chain of 50,000 steps with 40,000 steps of burn-in and a thinning interval of 100 steps. Populations were defined using a threshold of 0.5 on probability of membership of individuals, as recommended in the bGMYC manual. As bGMYC is a single-locus method for species delimitation, it is sensitive to processes that generate gene tree-species tree discordance (Degnan and Rosenberg, 2009) and may lead to generalized oversplitting (Miralles and Vences, 2013).

The two methods described above have their own caveats and neither can be considered optimal for the discovery of new lineages (Carstens et al., 2013). Thus, because both methods showed largely concordant results (see Fig. 1 and Section 3 for more details), we combined all the genetic breaks found by both methods and tested them using the Bayesian Phylogenetics and Phylogeography species delimitation method (BPP3) (Yang and Rannala, 2010). BPP is a multi-locus method that implements a reversible jump MCMC algorithm under the multispecies coalescent model to estimate jointly the number of species and the species tree. It has been shown that populations that exchange one or more migrants per generation are lumped in a single species (Zhang et al., 2011; Rannala, 2015). Therefore, BPP is a molecular method that can objectively validate lineages that are evolving independently and are not exchanging migrants at a high rate. For this analysis we used only three nuclear genes because, for individuals from one of the groups (representing the type locality), we had no data for the POMC fragment. The mitochondrial gene fragment was not included because preliminary analysis including this fragment showed poor chain mixing. We ran BPP with four different prior combinations for population size (theta) and divergence time (tau) parameters (Leaché and Fujita, 2010): (i) large ancestral population sizes and ancient divergence $[G(1,10)$ for both parameters]; (ii) large population sizes and recent divergences [G $(1,10)$ for theta; and $G(2,2000)$ for tau]; (iii) small population sizes and recent divergences [G(2,2000) for both parameters]; and (iv) small population sizes and deep divergences $[G(2,2000)$ for theta; and $\mathrm{G}(1,10)$ for tau]. We ran all prior combinations at least three times using both algorithms ( 0 and 1 ) and adjusted the finetuning to ensure swapping rates between 0.30 and 0.70 . Each run consisted of a burn-in phase of 100,000 iterations followed by a sampling phase of $1,000,000$ iterations, with a frequency of 100 iterations per sampling.

\subsection{Species tree analysis and divergence times}

We estimated a dated species tree using the mitochondrial $16 \mathrm{~S}$ segment and all nuclear segments of all samples in *BEAST 1.8.0 software (Drummond et al., 2012). We grouped the individuals into 10 populations maximizing the number of breaks according to the results of the STRUCTURE and bGMYC analyses. To calibrate the gene tree we estimated substitution rate for the 16S and RAG1 fragments for terraranas, i.e., frogs of the Brachycephaloidea group.

For each gene we downloaded sequences of several species of terraranas (Table S4). We calculated the best substitution model using jModelTest. For both genes we used the GTR+I+G substitution model, a Yule speciation tree prior, and a lognormal relaxed clock model. To calibrate the trees we applied uniform priors on four divergence times following Heinicke et al. (2007) for both analyses: (i) maximum divergence time of 10 Mya for the Jamaican radiation of the subgenus Euhyas; (ii) maximum divergence time of 10 Mya for the Hispaniolan South Island radiation of Euhyas; (iii) minimum divergence time of 15 Mya between Eleutherodactylus and Pelorius; and (iv) a minimum of 35 Mya and maximum of 70 Mya for the divergence between South American and Australian hylids. For each analysis we ran the MCMC for 20,000,000 generations sampling every 2,000 generations. We used the posterior mean of the ucld.mean parameter as an estimate of substitution rate after $10 \%$ of burn-in. 
(a)

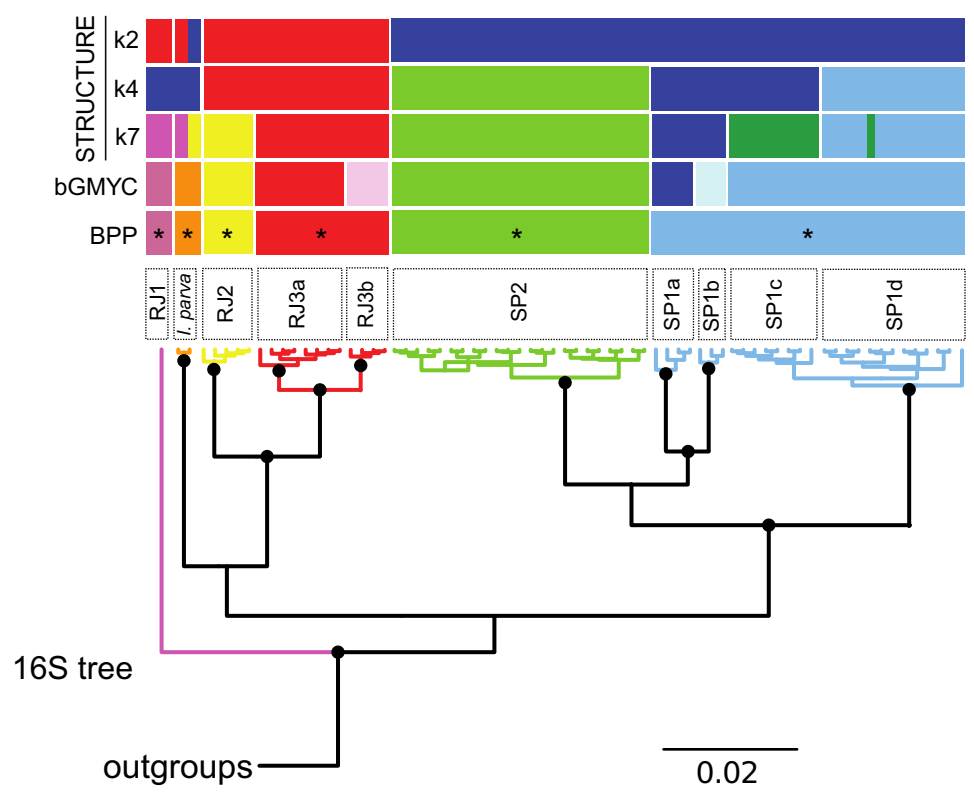

(b) RAG1
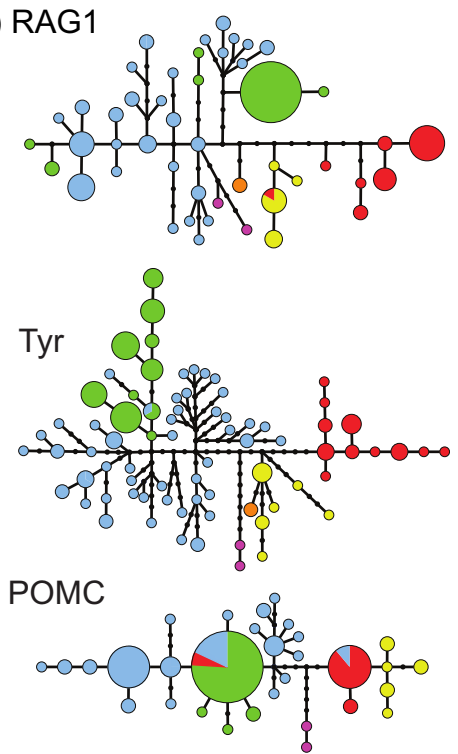

H3

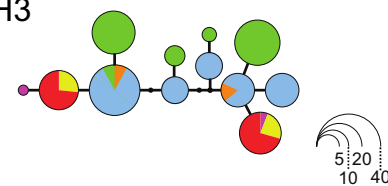

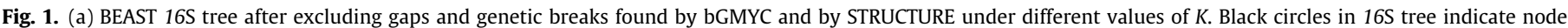

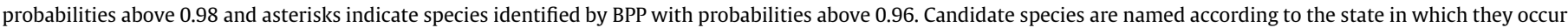

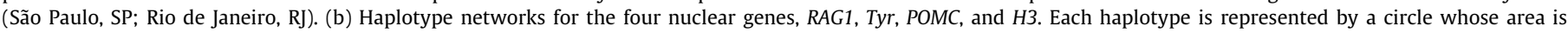

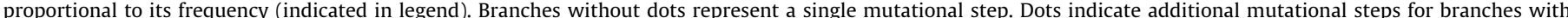

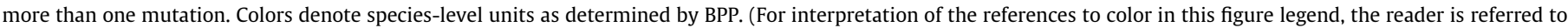
the web version of this article.)

To run the species tree we fixed the substitution rates of RAG1 and $16 S$ accordingly at $0.0015 /$ site/Mya and $0.006 /$ site/Mya, respectively. Substitution rates of the other gene segments were coestimated by the program. We assumed a relaxed clock model with uncorrelated lognormal distribution for the mitochondrial segment and a strict clock for the nuclear segments, and a birthdeath tree prior (see Table S3 for details about substitution models). We ran the MCMC chain for 100,000,000 iterations, sampling every 10,000 iterations, from which $10 \%$ were discarded as burn-in. To check for convergence of results, we performed four independent analyses using different seed numbers. Parameter sampling, convergence and chain mixing were visually checked using TRACER. The species tree was summarized in Tree Annotator and visualized in FigTree 1.5 (Rambaut, 2014).

\subsection{Migration}

Populations that were lumped by BPP into a single species are likely exchanging high levels of migrants among each other, while migration is probably absent or low between highly supported species (see Rannala, 2015). Thus, for the four lineages that were joined into a single species in São Paulo coast (SP1), we ran MIGRATE-N 3.6 (Beerli, 2006) to test if the migration rates are in agreement with the expectations of non-independently evolving populations. Two of these lineages are found only on the mainland of São Paulo State (SP1b and SP1d; see Figs. 2 and 3, and Section 3 for more details); one lineage occurs at the São Sebastião island (SP1c; Fig. 2); and one lineage occurs in the mainland and in Mar Virado island (SP1a; Fig. 2). We considered the four lineages plus the population of Mar Virado island as an additional population in MIGRATE-N analyses, making five populations altogether.
MIGRATE-N implements an island model to estimate population sizes and migration rates. A full-migration model with five populations has a large amount of parameters (five Ne parameters and 20 migration parameters), which are difficult to estimate with the data at hand. Therefore, we implemented a five-populations island model with two parameters only, one population size and one migration rate. In this case, the estimated population size represents the average size among all populations. Similarly, the migration rate represents the average migration among all populations. We ran the Bayesian version of MIGRATE-N using the default uniform prior for population size and specified uniform prior on migration rates $(0-10,000)$. We set up a fixed mutation rate for each gene according to the mean of the posterior estimate of the clock rates estimated by "BEAST (Table S5). We set up an MCMC with 1,000,000 iterations (10,000 samples; 100 thinning), and discarded the first 100,000 steps as burn-in.

\subsection{Mode and time of diversification on continental islands}

To test the mode and time of diversification between islands and mainland we used approximate Bayesian computation (ABC). The $A B C$ method uses simulations to infer model probabilities and the respective parameters without likelihood. We performed coalescent simulations of two-population divergence models that represent three hypotheses: (a) PreLGM-IS, where populations got isolated before the LGM, from 20 to 2,500 Kyr, without gene flow; (b) PreLGM-IM, where populations got isolated in the same time but with the presence of gene flow along the process; and (c) PostLGM-IS, where populations on island got isolated recently without gene flow, from 5 to $20 \mathrm{Kyr}$ (see Fig. 3 and Section 3 for more details). These hypotheses were tested for two sets of data: 
(b)

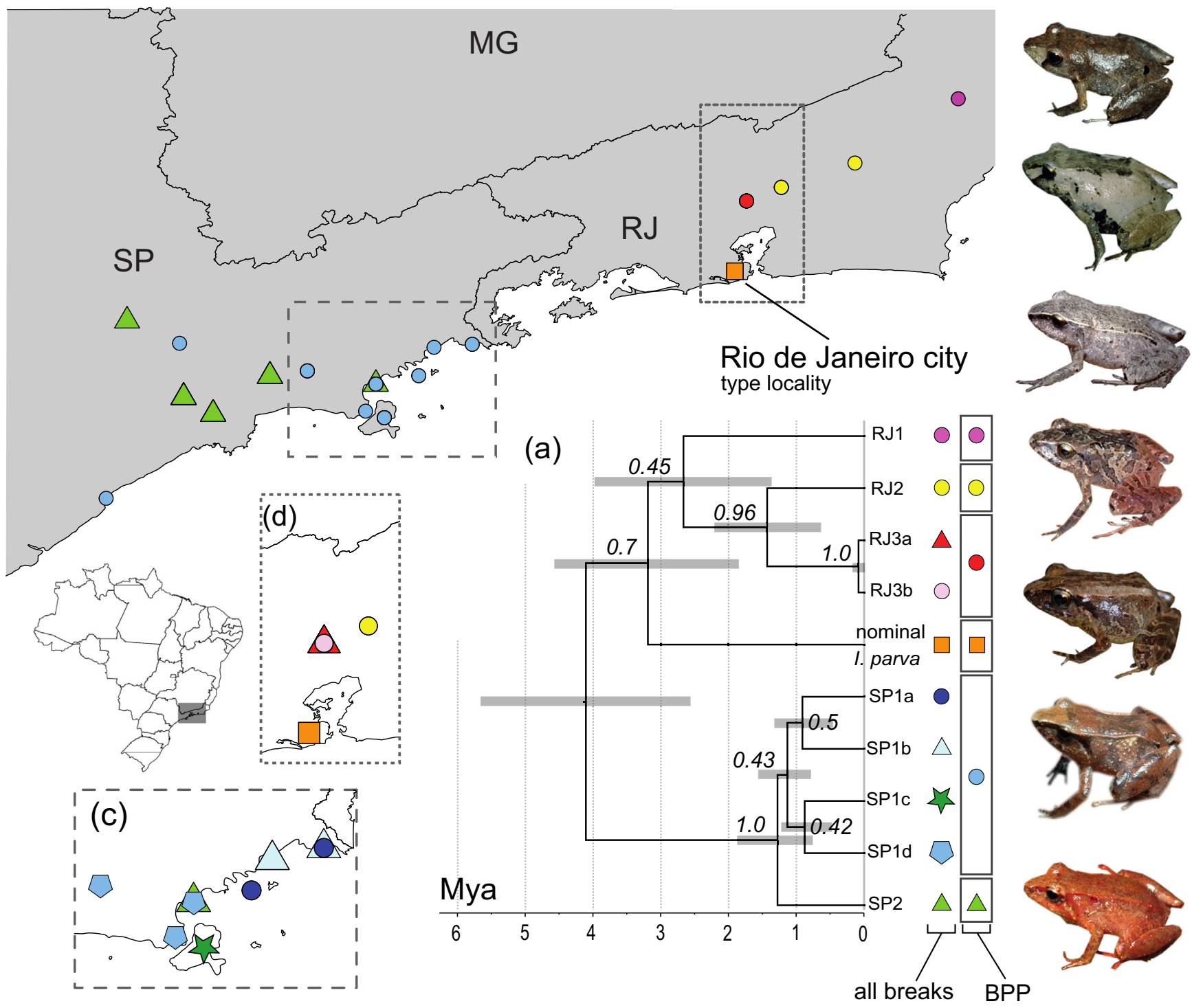

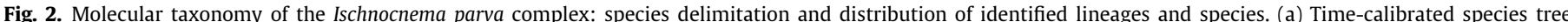

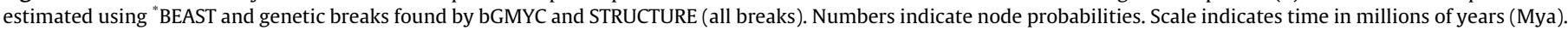

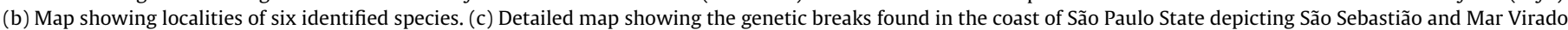

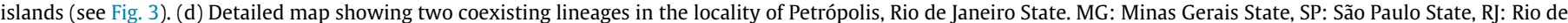
Janeiro State. Photos show morphological variation in the I. parva complex (specimens not reliably assignable to lineages).

(i) the divergence between all individuals of population SP1c (São Sebastião island) and SP1d (mainland) (Figs. 2a-c and 3); and (ii) the divergence between the two localities where population SP1a occurs, Mar Virado island and Picinguaba, both in the municipality of Ubatuba, state of São Paulo (Figs. 2a-c and 3). We used the beta version of PipeMaster 0.0.7 R-package (Gehara et al., unpublished) ( $\mathrm{R}$ Core Team, 2016) available in Github (http://github.com/gehara/PipeMaster) to sample parameters from uniform prior distributions, to simulate data and to calculate summary statistics. PipeMaster simulates data using $m s$ coalescent simulator (Hudson, 2002), which is implemented as a function in Phyclust 0.1-16 R-package (Chen, 2011), and pass ms outputs to PopGenome 2.1.6 R-package (Pfeifer et al., 2014) for summary statistics calculation. For each parameter we assumed fairly wide uniform priors that encompassed the estimated $\mathrm{Ne}$ and migration from the MIGRATE-N results (see Table S6 for details). For each simula- tion we sampled a single value for population parameters and specific mutation rates for each gene. We used the mutation rates, inheritance factors of each gene and number of base pairs to rescale the population parameters to coalescent values according to the $m s$ manual. For each gene we calculated a group of summary statistics: (i) number of segregating sites per population and overall; (ii) nucleotide diversity per population and overall; (iii) haplotype diversity per population and overall; (iv) haplotype-based fixation index, Fst; and (v) the distance-based fixation index (PHIst). The values were averaged across all genes, and we used the same approach to calculate the statistics on our observed data. We performed 1,000,000 simulations per model and evaluated the model-fit using a principal component analysis (PCA) on 10,000 simulations and the observed data (Fig. S5). We performed the $\mathrm{ABC}$ rejection and regression algorithms to evaluate the probability of each model and to estimate model parameters using the abc 2.1 
(a)
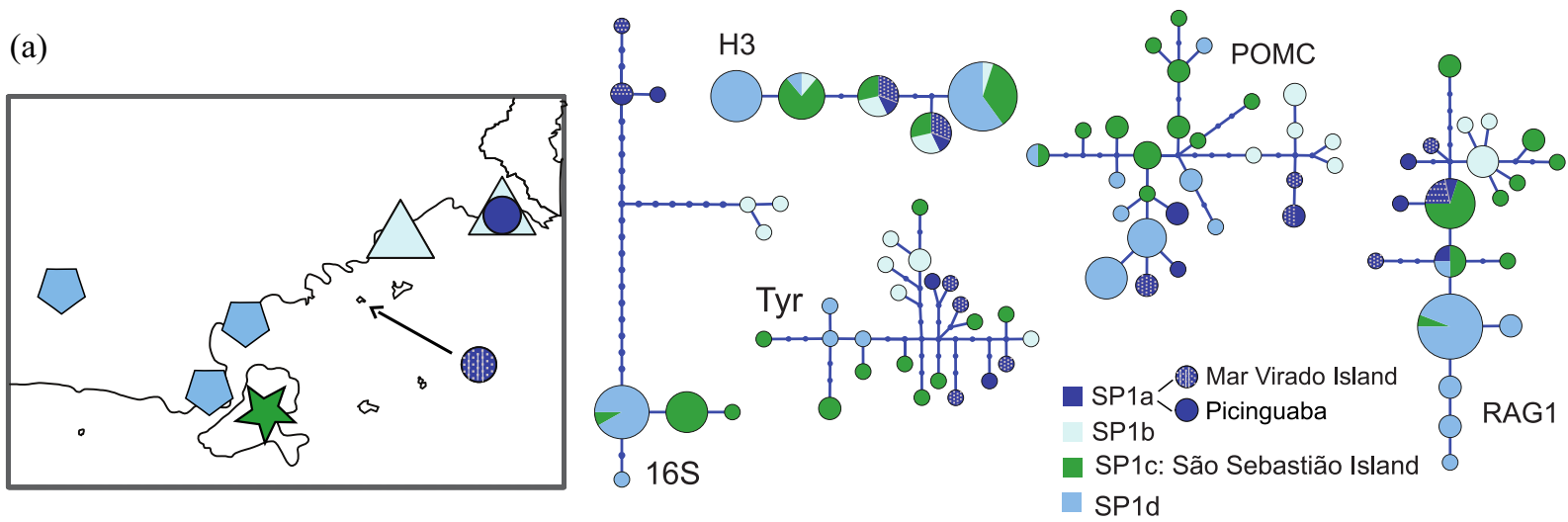

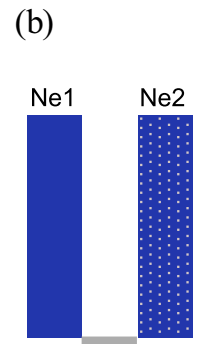

$\mathrm{T} 1$ 0.01
0.01

PreLGM-IS

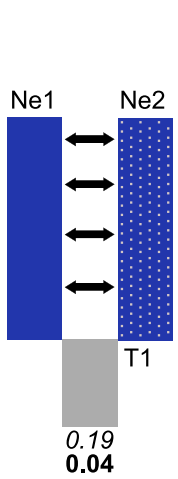

PreLGM-IM

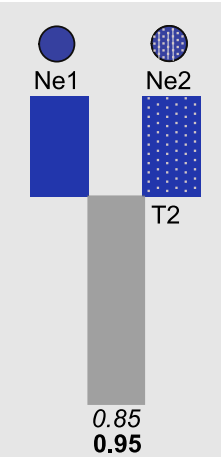

PostLGM-IS (c)

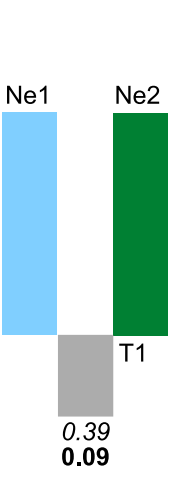

PreLGM-IS

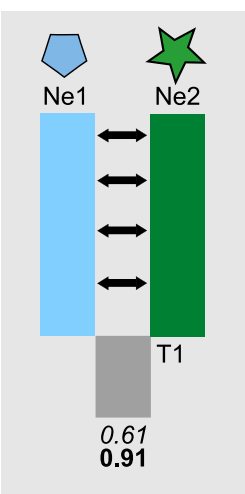

PreLGM-IM

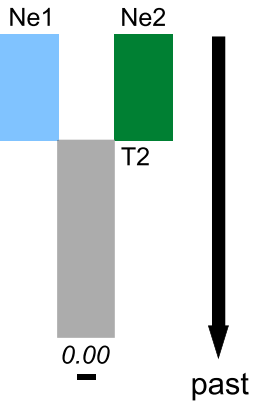

PostLGM-IS

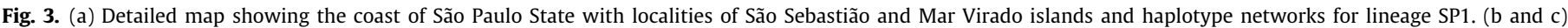

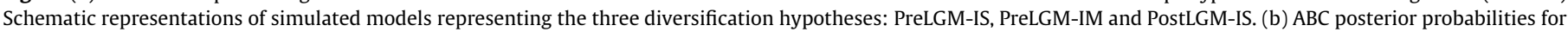

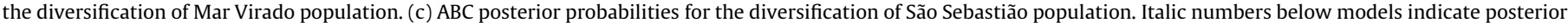
probabilities using the Rejection algorithm and bold numbers the Neural Network algorithm from the abc R-package.

R-package (Csilléry et al., 2012). We used the same package to perform a leave-one-out cross-validation to calculate the misclassification proportions (Fig. S6). To infer the probability of each model we used the Neural Network machine-learning algorithm on the $\sim 300$ closest simulations ( 0.0001 tolerance level) obtained using the rejection algorithm, both implemented in the abc Rpackage. As Neural Network settings we used 20 neural nets and 10 layers with maximum 2,000 iterations and no correction for heteroscedasticity. The same settings were used to estimate the parameters of the model with the highest probability.

\section{Results}

The final alignment for the mitochondrial gene (16S) preserved $\sim 82 \%$ (371 bp) of its original size after gap exclusion by GBLOCKS. The 165 gene tree recovers all samples a priori assigned to Ischnocnema parva as a monophyletic group with 0.98 posterior probability (Fig. S2). Alignments of the nuclear gene segments included 372 bp of $H 3$ (26 variable sites), 415 bp of $P O M C$ ( 89 variable sites), 548 bp of RAG1 ( 85 variable sites), and 548 bp of Tyr (114 variable sites).

\subsection{Population assignment, species delimitation and overall migration}

The population assignment test of STRUCTURE identified an optimal value of two clusters with additional suboptimal peaks on four and seven clusters (Fig. 1a and Fig. S3; see also Table S1). The bGMYC analysis identified nine mitochondrial clusters
(Fig. 1a and Fig. S4; see also Table S1). The two analyses revealed largely congruent breaks (Fig. 1a), with STRUCTURE showing one additional break between the mainland and São Sebastião island not identified by the bGMYC (SP1c and SP1d; Figs. 1a and 2a-c). In turn, the bGMYC revealed two coexisting lineages in the locality of Petrópolis, state of Rio de Janeiro (RJ3a and RJ3b; Figs. 1a and 2a, b, and d); grouped individuals from the type locality in an additional cluster (Figs. $1 \mathrm{a}$ and $2 \mathrm{a}, \mathrm{b}$, and d); and revealed two coexisting lineages in the coast of São Paulo state (SP1a and SP1b; Figs. 1a and 2a-c).

All of the four prior combinations used in BPP grouped the two lineages RJ3a and RJ3b in a single species with a probability of 1.0 (Fig. 1a). The runs using the combination of small population size and recent divergence $[G(2,2000)]$ grouped the lineages SP1a, SP1b, SP1c, and SP1d into a single species with probability $>0.96$ (Fig. 1a). Therefore, BPP analyses recognized six lineages with high posterior probability (see Fig. 1a). For those grouped lineages from São Paulo State, the MIGRATE-N estimate of overall migration rate was in agreement with a high exchange of migrant allele copies per generation $(2 \mathrm{Nm}=1.9 ; \mathrm{CI}=1-4.7)$, which justifies grouping them in a single species.

\subsection{Species tree and divergence times}

*BEAST and BPP recovered the same species tree topology (Fig. 2a). In accordance with the BPP results, "BEAST estimated low probabilities for the internal nodes splitting SP1a, b, $c$ and $d$. The resulting tree from ${ }^{*}$ BEAST shows an early ancient divergence 
between species from São Paulo and Rio de Janeiro states around 4.1 Mya. While posterior probabilities for the São Paulo group are high $(\mathrm{p}=1.0)$, the node support for the Rio de Janeiro group is relatively low $(p=0.71)$. Early diversification within the Rio de Janeiro group predates the Pleistocene and is estimated at around 3.2 Mya and 2.7 Mya. Conversely, the São Paulo group started to diversify much later, during the Pleistocene around 1.3 Mya (Fig. 2a), at approximately the same time as the later diversifications of Rio de Janeiro group ( 1.5 Mya).

\subsection{Haplotype networks}

Haplotype networks showed a high genetic variation in nuclear gene haplotypes of I. parva (Fig. 1b), but only a few of these haplotypes were shared among individuals of different lineages. We observed 12 distinct haplotypes for $\mathrm{H3}$, of which four showed instances of haplotype sharing, 31 haplotypes for POMC (2 shared), 47 haplotypes for RAG1 (1 shared), and 76 haplotypes for Tyr (1 shared). Haplotype sharing among lineages from states of São Paulo versus Rio de Janeiro was observed only for $\mathrm{H} 3$ and POMC.

In general, all samples from one locality belonged to only one lineage. However, in one instance we observed sympatry of two lineages. Of six samples from the location Caraguatatuba-SP, one was assigned to SP2 (CFBH-T3829) and five to SP1 (CFBH-T3816, T3817, T3819 T3822, T3823), without any indication of admixture (no haplotype sharing for $H 3, P O M C$, and RAG1, one haplotype shared for Tyr).

Haplotype networks for lineage SP1 showed several instances of haplotype sharing between mainland and continent. The networks also showed a high amount of incomplete lineage sorting, indicating the presence of gene flow and/or recent divergence relative to population size (Fig. 3a).

\subsection{Mode and time of diversification on continental islands}

The $A B C$ diversification models showed a good fit to the data as seen by the PCA (Fig. S5). The models are well differentiated and correctly classified for most cases, particularly when using the Neural Network regression (Fig. S6). For São Sebastião island, the model with the highest probability is the PreLGM-IM $(P P=0.91)$, which assumes ongoing migration throughout the diversification process (Fig. 3c). For Mar Virado island we found that the model with the highest probability is the PostLGM-IS ( $\mathrm{PP}=0.95$ ), which assumes a later divergence without migration after isolation (Fig. 3b). The mode of the posterior densities for effective population size for SP1d (mainland) was $\sim 290,000$ while for São Sebastião island it was $\sim 789,000$ (Table 1 ). Divergence time was estimated at $\sim 1,000,000$ years, and migration was somewhat asymmetric, with more gene flow towards the island $(2 \mathrm{Nm}=1.6)$ versus the continent $(2 \mathrm{Nm}=0.9)$ (Table 1$)$. Effective population-size estimates for Mar Virado island and Picinguaba (both from lineage SP1a) were similar, $\sim 600,000$ and $\sim 611,000$, respectively. Divergence time estimate was at $\sim 13,400$ years (Table 2 ).
Table 2

$\mathrm{ABC}$ parameter estimates using the Neural Network regression for divergence between Picinguaba and Mar Virado island under the PostLGM-IS model (Fig. 3b). Ne1: effective population size of the mainland population (Picinguaba); Ne2: effective population size of Mar Virado island population; T2: divergence time between Mar Virado and mainland.

\begin{tabular}{llll}
\hline & Ne1 & Ne2 & T2 \\
\hline Min. & 284,174 & 260,999 & 3,772 \\
Weighted 2.5\% Perc. & 408,758 & 393,897 & 9,427 \\
Weighted median & 615,849 & 600,764 & 13,537 \\
Weighted mean & 621,902 & 610,771 & 13,418 \\
Weighted mode & 611,417 & 599,485 & 13,402 \\
Weighted 97.5\% Perc. & 862,169 & 787,936 & 16,221 \\
Max. & 951,453 & $1,157,962$ & 23,346 \\
\hline
\end{tabular}

\section{Discussion}

\subsection{Diversification of Ischnocnema parva complex in the southern Atlantic forest}

We found six independently evolving populations in a small area of southern AF. This suggests low or no long-term gene flow, even between proximate localities, a pattern also encountered in other amphibian species with similar biology (Fouquet et al., 2012; Gehara et al., 2013; Tonini et al., 2013; Firkowski et al., 2016). Frogs of the I. parva complex are forest-dwellers and depend on moist leaf-litter for reproduction (Martins et al., 2010). It is very unlikely that they could survive long periods of drought. Also, ecological studies report higher estimates of population density of $I$. parva for higher altitudes, which suggests that these species are better adapted to colder humid climates (Rocha et al., 2001, 2007; Siqueira et al., 2009; Martins et al., 2010). Therefore, species of the I. parva complex can be considered good indicators of humidity and forest stability. The Pliocene and Pleistocene divergences among highland lineages may indicate an influence of climatic cycles and a role of mountains in diversification mechanisms. During the Pliocene the temperature was $2-3^{\circ} \mathrm{C}$ higher than today (Robinson et al., 2008), and some studies indicate that the climate of Brazil's southeast was drier (Simpson, 1979; Vasconcelos et al., 1992). With the transition to the Pleistocene, climate started to oscillate with periods of wet climate intercalating periods of drier climate. It has been suggested that montane tropical forests were less affected by aridification and could remain more stable during climatic shifts (Haffer, 1969; Wilmé et al., 2006). Thus, temperature warming and/or forest fragmentation in the lowland could have caused extinctions in the lowlands and vertical displacement of populations to the highlands, promoting diversification in isolated mountain refugia (Smith et al., 2007; Wollenberg et al., 2008; Wiens et al., 2010; d'Horta et al., 2011; Velo-Antón et al., 2013).

The persistence of ancient diversified lineages of I. parva in SP, and particularly in RJ, supports the existence of stable refuges that could sustain viable populations of I. parva in the southern portion of the AF, at least in the highlands. Hence, mountains may have played an important role in the diversification of cold-adapted

Table 1

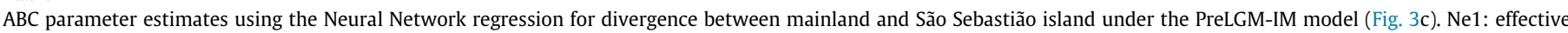

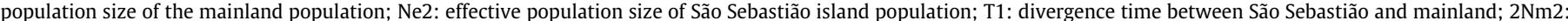

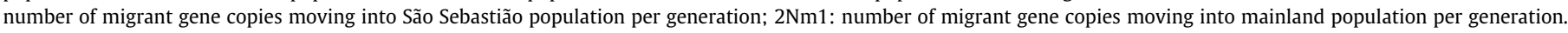

\begin{tabular}{|c|c|c|c|c|c|}
\hline & Ne1 & $\mathrm{Ne} 2$ & $\mathrm{~T} 1$ & $2 \mathrm{Nm} 1$ & $2 \mathrm{Nm} 2$ \\
\hline Min. & $-2,610$ & 193,627 & $-52,729$ & -0.28 & -0.91 \\
\hline Weighted 2.5\% Perc. & 123,070 & 409,380 & 464,046 & 0.21 & 0.56 \\
\hline Weighted median & 294,188 & 700,350 & $1,326,353$ & 1.11 & 2.01 \\
\hline Weighted mean & 316,931 & 694,090 & $1,378,790$ & 1.25 & 2.12 \\
\hline Weighted mode & 289,249 & 788,944 & $1,022,691$ & 0.91 & 1.60 \\
\hline Weighted 97.5\% Perc. & 681,480 & 986,655 & $2,376,150$ & 3.36 & 4.01 \\
\hline Max. & 954,357 & $1,087,831$ & $2,883,480$ & 4.33 & 5.31 \\
\hline
\end{tabular}


populations in southern AF by allowing vertical displacement throughout temperature cycles (Carnaval et al., 2014). The phylogeographical patterns found in other frogs with similar distributions, particularly other direct-developing frogs, corroborate this hypothesis (Clemente-Carvalho et al., 2011; Amaro et al., 2012; Gehara et al., 2013; Menezes et al., 2016).

\subsection{Insular diversification in the $A F$}

We found that populations of I. parva on continental islands of the AF have originated before and after the LGM. In São Sebastião island, the insular population has a pre-LGM divergence history with the mainland ( $\sim 1$ Mya), while in Mar Virado island the divergence happened after the LGM ( $\sim 13 \mathrm{kyr})$. Thus, our results indicate the existence of relatively old divergence histories of frog populations on continental islands with gene flow with the mainland, but also instances of recent insular colonization during the LGM. The LGM was the last time most continental islands were connected to the mainland. They became again completely isolated during the Holocene when the relative sea level rose from about $-60 \mathrm{~m}$ to current levels (Fleming et al., 1998; Suguio et al., 2005). The estimated divergence time between mainland and Mar Virado populations falls close to the beginning of the Holocene ( $\sim 13,402$ years before present; CI: 9,427-16,221; Table 2), being remarkably concordant with the sea-level rise. Insular colonization during the LGM might have happened in other species and other continental islands of the Brazilian coast. For instance, tree frogs from Mar Virado island of the species Scinax perpusillus also present low genetic and morphological differentiation, consistent with colonization during the LGM and Holocenic isolation (Bell et al., 2012).

Differently, in the case of São Sebastião island, the best model suggests pre-LGM divergence with gene flow between continental island and mainland. This is in agreement with a dynamic process of isolation and reconnection of continental islands during climatic cycles of the Pleistocene. In this scenario, populations got isolated during interglacial times but gene flow happened during glacial periods. Therefore, although the colonization of São Sebastião island is relatively ancient, $\sim 1$ Mya, migration prevented the complete speciation of populations (Table 1). The pattern found in frogs of the Thoropa miliaris species complex from São Sebastião island is also consistent with the same process. This species shows sorted mitochondrial genes and relatively deep divergence between mainland and insular populations of São Sebastião island (Fitzpatrick et al., 2009).

According to island biogeography, island size and distance from the mainland influence species richness and abundance (MacArthur and Wilson, 1967; Brown, 1978; Heaney, 2007). Small distant islands will have high extinction rates and lower colonization rates. Both islands analyzed here have approximately the same distance from mainland (no more than $3 \mathrm{~km}$ ) and ocean depth is also similar (Suguio et al., 2005), but Mar Virado island is much smaller than São Sebastião island ( 1 versus $\left.\sim 350 \mathrm{~km}^{2}\right)$. Thus, it is less probable for individuals to reach Mar Virado island than São Sebastião island during glaciations, simply because of size. Also, newly colonized populations have a higher probability of extinction on small islands such as Mar Virado than on larger islands such as São Sebastião. Thus, the recent colonization of Mar Virado does not necessarily indicate that the island was only recently populated, but might also mean that ancient populations or ancient alleles went extinct along the Pleistocene. In São Sebastião island, populations might have persisted just because the extinction rate is lower. Because of the combined effects of lower dispersal probability and higher extinction probability of small islands, we might expect a higher proportion of recent colonization events in small islands and a higher proportion of ancient colonizations on larger islands of AF.
Although we have not performed an extensive morphological analysis, preliminary data suggest no clear morphological difference between insular and mainland populations. The same lack of morphological differentiation is found in frogs of the Scinax perpusillus group from Mar Virado island, as well as for populations of Thoropa miliaris from São Sebastião island. However, there are cases of morphologically differentiated endemic species in other continental islands, e.g. frogs of the genus Cycloramphus (Brasileiro et al., 2007b) and Scinax (Brasileiro et al., 2007a, 2007c). Besides morphological differentiation, there are cases of endemic insular species that show evidence of adaptations. For instance, the viper Bothrops insularis from Queimada Grande island has arboreal behavior and feeds on migratory birds, while its closest relative on the mainland, B. jararaca, is terrestrial and feeds primarily on small mammals. Likewise, B. alcatraz from Alcatrazes island is pedomorphic and feeds on ectothermic prey. In Moleques do Sul islands in the coast of Santa Catarina state, in Brazil, an endemic species of rodent (Cavia intermedia) shows a series of ecological adaptations typical for insular populations (Salvador and Fernandez, 2008). Those species complexes that show insular endemism and adaptations are interesting models to understand selection and morphological differentiation. With the advance of molecular technologies we can now use thousands of loci not only to investigate the mode and timing of diversification, but also to investigate adaptation in continental islands.

There are several continental islands with different sizes in the coast of Brazil; many of those islands are poorly known in terms of diversity. A more detailed survey on the AF coast may reveal additional endemic species with insular adaptations. Known examples like those of Queimada Grande, Alcatrazes and Moleques do Sul, represent unique genetic entities with high conservation priorities, and they are natural evolutionary experiments with high value for scientific studies of ecology and evolutionary biology.

\subsection{Taxonomic and conservation implications}

Understanding the true diversity of species and assessing their distributions constitute two of the major challenges in efficient conservation of tropical amphibian diversity, given the immense proportion of cryptic diversity uncovered by recent studies (e.g. Meegaskumbura et al., 2002; Stuart et al., 2006; Fouquet et al., 2007a, 2007b; Vieites et al., 2009; Funk et al., 2012; Rowley et al., 2015). Here we have used multilocus sequence data and molecular species delimitation to demonstrate that Ischnocnema parva comprises six species. We hypothesize that there are five new species among populations currently assigned to Ischnocnema parva, the nominal I. parva being the lineage found at the type locality. The species was described from "Rio de Janeiro" by Girard (1853), and it is uncertain in which collection the types have been deposited (Frost, 2016). The BPP results and the almost complete lack of haplotype sharing in nuclear genes suggest very limited or no gene flow among these lineages (Fig. 1). We consider that the lineages thereby defined constitute independently evolving units and thus qualify as separate species deserving a formal taxonomic description (de Queiroz, 2007; Padial et al., 2010; Weisrock et al., 2010).

A preliminary morphological screening of 17 voucher specimens from the CFBH collection, representing all of these candidate species, revealed a large amount of variation in color and partly in size, but no diagnostic characters. All specimens were apparently adults and agreed in morphology with the known characters of $I$. parva (e.g. distinct pointed toe discs with circumferential grooves; Heyer et al., 1990). Specifically, none of them had a calcar tubercle diagnostic for the recently described I. nanahallux (Brusquetti et al., 2013). This morphological feature and the genetic data exclude the possibility of confusion with this species, which probably repre- 
sents the sister taxon of the I. parva complex (Brusquetti et al., 2013; Padial et al., 2014).

Our data serve to outline priorities for a future taxonomic revision of the I. parva complex. According to our data, there is a strong concordance between mitochondrial and nuclear genetic differentiation in this species complex, suggesting that a preliminary screening for a simple mtDNA marker will be sufficient to assign specimens to lineages and to improve our knowledge on their geographic distributions. Sampling should focus especially on southern Rio de Janeiro State to fill gaps between RJ and SP lineages, and on northern Rio de Janeiro State and adjacent Minas Gerais State, where I. parva is known to occur but has so far not been sampled for molecular analysis. Given that it is unlikely to find unambiguous morphological characters to diagnose the various species in the complex, a priority should be obtaining recordings of advertisement calls from genotyped specimens in order to understand possible premating isolating barriers between them. Of particular interest are areas of sympatry or syntopy of various lineages, because evidence for syntopic occurrence without admixture would conform to the biological species criterion and thus conclusively demonstrate species status.

The results presented herein also bear relevance on the conservation status of Ischnocnema parva. At present, the species is considered Non Threatened in the IUCN Red List (Van Sluys and Da Rocha, 2010), although local declines have been noted (Eterovick et al., 2005). According to current information, several of the species identified herein are relatively widespread (e.g. SP1 and SP2), although their range is distinctly smaller than that of I. parva as defined by current taxonomy. Several other species might be true microendemic, and their threat status need to be carefully revisited. We expect that some of them might qualify for one of the threatened categories of IUCN.

\section{Acknowledgments}

We are grateful to Meike Kondermann and Gabi Keunecke for help in the lab; Jose P. Pombal Jr. and Clarissa Canedo for providing tissue samples from Museu Nacional - UFRJ (National Museum of Brazil); CAPES (Coordenação de Aperfeiçoamento de Pessoal de Nível Superior), DAAD (Deutscher Akademischer Austauschdienst), and FAPESB (Fundação de Amparo a Pesquisa do Estado da Bahia) provided financial support to the $\mathrm{PhD}$ project of $\mathrm{AB}$. KAAD (Katholischer Akademischer Ausländer-Dienst) provided financial support to MG. We are further indebted to CNPq (Conselho Nacional de Desenvolvimento Científico e Tecnológico) for supporting the research and to ICMBio for providing collecting permit to MG (21710-2). MV was supported by a CAPES "Pesquisador Visitante Especial - Ciência sem Fronteiras" fellowship. CFBH thanks grant \#2013/50741-7, Fundação de Amparo à Pesquisa do Estado de São Paulo (FAPESP) and CNPq, for financial support.

\section{Appendix A. Supplementary material}

Supplementary data associated with this article can be found, in the online version, at http://dx.doi.org/10.1016/j.ympev.2017.04. 007.

\section{References}

Amaro, R.C., Rodrigues, M.T., Yonenaga-Yassuda, Y., Carnaval, A.C., 2012. Demographic processes in the montane Atlantic rainforest: molecular and cytogenetic evidence from the endemic frog Proceratophrys boiei. Mol. Phylogenet. Evol. 62, 880-888. doi:S1055-7903(11)00463-5 [pii]10.1016/j. ympev.2011.11.004.

Batalha-Filho, H., Fjeldså, J., Fabre, P.H., Miyaki, C.Y., 2013. Connections between the Atlantic and the Amazonian forest avifaunas represent distinct historical events. J. Ornithol. 154, 41-50. http://dx.doi.org/10.1007/s10336-012-0866-7.
Beerli, P., 2006. Comparison of Bayesian and maximum-likelihood inference of population genetic parameters. Bioinformatics 22, 341-345. http://dx.doi.org/ 10.1093/bioinformatics/bti803.

Bell, R.C., Brasileiro, C.A., Haddad, C.F.B., Zamudio, K.R., 2012. Evolutionary history of Scinax treefrogs on land-bridge islands in south-eastern Brazil. J. Biogeogr. 39, 1733-1742. http://dx.doi.org/10.1111/j.1365-2699.2012.02708.x.

Bertoluci, J., Rodrigues, M.T., 2002. Seasonal patterns of breeding activity of Atlantic Rainforest anurans at Boracéia, Southeastern Brazil. Amphibia-Reptilia 23, 161 167. http://dx.doi.org/10.1163/156853802760061804.

Brasileiro, C.A., Haddad, C.F.B., Sawaya, R.J., Martins, M., 2007a. A new and threatened species of Scinax (Anura: Hylidae) from Queimada Grande Island, southeastern Brazil. Zootaxa 55, 47-55.

Brasileiro, C.A., Haddad, C.F.B., Sawaya, R.J., Sazima, I., 2007b. A new and threatened island-dwelling species of Cycloramphus (Anura: Cycloramphidae) from southeastern Brazil. Herpetologica 63, 501-510. http://dx.doi.org/10.1655/ 0018-0831(2007) 63[501:ANATIS]2.0.CO;2.

Brasileiro, C.A., Oyamaguchi, H.M., Haddad, C.F.B., 2007c. A new island species of Scinax (Anura; Hylidae) from Southeastern Brazil. J. Herpetol. 41, 271-275. http://dx.doi.org/10.1670/0022-1511(2007) 41[271:ANISOS]2.0.CO;2.

Brown, J., 1978. The theory of insular biogeography and the distribution of boreal birds and mammals. Gt. Basin Nat. Mem. 2, 209-227.

Bruford, M.W., Hanotte, O., Brookfield, J.F.Y., Burke, T., Hoelzel, A.R., 1992. Singlelocus and multilocus DNA fingerprint. In: Molecular Genetic Analysis of Populations: A Practical Approach. IRL Press, Oxford, pp. 225-270.

Brusquetti, F., Thomé, M.T.C., Canedo, C., Condez, T.H., Haddad, C.F.B., 2013. A new species of Ischnocnema parva species series (Anura, Brachycephalidae) from northern state of Rio de Janeiro, Brazil. BioOne 69, 175-185. http://dx.doi.org/ 10.1655/HERPETOLOGICA-D-12-00050.

Canedo, C., Haddad, C.F.B., 2012. Phylogenetic relationships within anuran clade Terrarana, with emphasis on the placement of Brazilian Atlantic rainforest frogs genus Ischnocnema (Anura: Brachycephalidae). Mol. Phylogenet. Evol. 65, 610 620. http://dx.doi.org/10.1016/j.ympev.2012.07.016.

Carnaval, A.C., Hickerson, M.J., Haddad, C.F.B., Rodrigues, M.T., Moritz, C., 2009 Stability predicts genetic diversity in the Brazilian Atlantic forest hotspot Science 323, 785-789. http://dx.doi.org/10.1126/science.1166955.

Carnaval, A.C., Moritz, C., 2008. Historical climate modelling predicts patterns of current biodiversity in the Brazilian Atlantic forest. J. Biogeogr. 35, 1187-1201. http://dx.doi.org/10.1111/j.1365-2699.2007.01870.x.

Carnaval, A.C., Waltari, E., Rodrigues, M.T., Rosauer, D., VanDerWal, J., Damasceno, R., Prates, I., Strangas, M., Spanos, Z., Rivera, D., Pie, M.R., Firkowski, C.R. Bornschein, M.R., Ribeiro, L.F., Moritz, C., 2014. Prediction of phylogeographic endemism in an environmentally complex biome. Proc. R. Soc. B Biol. Sci. 281 20141461. http://dx.doi.org/10.1098/rspb.2014.1461.

Carstens, B.C., Pelletier, T.A., Reid, N.M., Satler, J.D., 2013. How to fail at species delimitation. Mol. Ecol. http://dx.doi.org/10.1111/mec.12413.

Castresana, J., 2000. Selection of conserved blocks from multiple alignments for their use in phylogenetic analysis. Mol. Biol. Evol. 17, 540-552. http://dx.doi. org/10.1093/oxfordjournals.molbev.a026334.

Chen, W.C., 2011. Overlapping Codon Model, Phylogenetic Clustering, and Alternative Partial Expectation Conditional Maximization Algorithm. Iowa State University.

Clemente-Carvalho, R.B., Klaczko, J., Ivan Perez, S., Alves, A.C., Haddad, C.F., dos Reis S.F., 2011. Molecular phylogenetic relationships and phenotypic diversity in miniaturized toadlets, genus Brachycephalus (Amphibia: Anura: Brachycephalidae). Mol. Phylogenet. Evol. 61, 79-89. doi:S1055-7903(11) 00259-4 [pii]10.1016/j.ympev.2011.05.017.

Condez, T.H., Clemente-Carvalho, R.B.G., Haddad, C.F.B., dos Reis, S.F., 2014. A new species of Brachycephalus (Anura: Brachycephalidae) from the highlands of the Atlantic Forest, Southeastern Brazil. Herpetologica 70, 89-99. http://dx.doi.org/ 10.1655/HERPETOLOGICA-D-13-00044.

Costa, L.P., 2003. The historical bridge between the Amazon and the Atlantic Forest of Brazil: a study of molecular phylogeography with small mammals. J. Biogeogr. 30, 71-86. http://dx.doi.org/10.1046/j.1365-2699. 2003.00792.x.

Csilléry, K., François, O., Blum, M.G.B., 2012. Abc: An R package for Approximate Bayesian Computation (ABC). Meth. Ecol. Evol. 3, 475-479. http://dx.doi.org/ 10.1111/j.2041-210X.2011.00179.x.

d'Horta, F.M., Cabanne, G.S., Meyer, D., Miyaki, C.Y., 2011. The genetic effects of Late Quaternary climatic changes over a tropical latitudinal gradient: diversification of an Atlantic Forest passerine. Mol. Ecol. 20, 1923-1935. http://dx.doi.org/ 10.1111/j.1365-294X.2011.05063.x.

Darriba, D., Taboada, G.L., Doallo, R., Posada, D., 2012. JModelTest 2: more models, new heuristics and parallel computing. Nat. Meth. 9, 772. http://dx.doi.org/ 10.1038/nmeth.2109.

de Queiroz, K., 2007. Species concepts and species delimitation. Syst. Biol. 56, 879886. http://dx.doi.org/10.1080/10635150701701083.

Degnan, J.H., Rosenberg, N.A., 2009. Gene tree discordance, phylogenetic inference and the multispecies coalescent. Trends Ecol. Evol. 24, 332-340. http://dx.doi. org/10.1016/j.tree.2009.01.009.

Drummond, A.J., Suchard, M.A., Xie, D., Rambaut, A., 2012. Bayesian phylogenetics with BEAUti and the BEAST 1.7. Mol. Biol. doi:mss075 [pii]10.1093/molbev/ mss075.

Earl, D., vonHoldt, B., 2012. STRUCTURE HARVESTER: a website and program for visualizing STRUCTURE output and implementing the Evanno method. Conserv. Genet. Resour. 4, 359-361. http://dx.doi.org/10.1007/s12686-011 9548-7. 
Eterovick, P.C., Carnaval, A.C.O.Q., Borges-Nojosa, D.M., Silvano, D.L., Segalla, M.V., Sazima, I., 2005. Amphibian declines in Brazil: an overview. Biotropica, 166 179.

Evanno, G., Regnaut, S., Goudet, J., 2005. Detecting the number of clusters of individuals using the software STRUCTURE: a simulation study. Mol. Ecol. 14, 2611-2620. doi:MEC2553 [pii]10.1111/j.1365-294X.2005.02553.x.

Falush, D., Stephens, M., Pritchard, J.K., 2003. Inference of population structure using multilocus genotype data: linked loci and correlated allele frequencies. Genetics 164, 1567-1587.

Firkowski, C.R., Bornschein, M.R., Ribeiro, L.F., Pie, M.R., 2016. Species delimitation, phylogeny and evolutionary demography of co-distributed, montane frogs in the southern Brazilian Atlantic Forest. Mol. Phylogenet. Evol. 100, 345-360. http://dx.doi.org/10.1016/j.ympev.2016.04.023.

Fitzpatrick, S.W., Brasileiro, C.A., Haddad, C.F.B., Zamudio, K.R., 2009. Geographical variation in genetic structure of an Atlantic Coastal Forest frog reveals regional differences in habitat stability. Mol. Ecol. 18, 2877-2896. http://dx.doi.org 10.1111/j.1365-294X.2009.04245.X.

Fleming, K., Johnston, P., Zwartz, D., Yokoyama, Y., Lambeck, K., Chappell, J., 1998. Refining the eustatic sea-level curve since the Last Glacial Maximum using farand intermediate-field sites. Earth Planet. Sci. Lett. 163, 327-342. http://dx.doi. org/10.1016/S0012-821X(98)00198-8.

Fouquet, A., Gilles, A., Vences, M., Marty, C., Blanc, M., Gemmell, N.J., 2007a. Underestimation of species richness in Neotropical frogs revealed by mtDNA analyses. PLoS One 2, e1109. http://dx.doi.org/10.1371/journal.pone. 0001109.

Fouquet, A., Loebmann, D., Castroviejo-Fisher, S., Padial, J.M., Orrico, V.G.D., Lyra, M L., Roberto, I.J., Kok, P.J.R., Haddad, C.F.B., Rodrigues, M.T., 2012. From Amazonia to the Atlantic Forest: molecular phylogeny of Phyzelaphryninae frogs reveals unexpected diversity and a striking biogeographic pattern emphasizing conservation challenges. Mol. Phylogenet. Evol. 65, 547-561. http://dx.doi. org/10.1016/j.ympev.2012.07.012.

Fouquet, A., Vences, M., Salducci, M.D., Meyer, A., Marty, C., Blanc, M., Gilles, A. 2007b. Revealing cryptic diversity using molecular phylogenetics and phylogeography in frogs of the Scinax ruber and Rhinella margaritifera species groups. Mol. Phylogenet. Evol. 43, 567-582. doi:S1055-7903(06)00488-X [pii 10.1016/j.ympev.2006.12.006.

Frost, Darrel R., 2016. Amphibian Species of the World: an Online Reference. Version 6.0 (Date of access). Electronic Database accessible at <http://research. amnh.org/herpetology/amphibia/index.html>. American Museum of Natural History, New York, USA.

Fujisawa, T., Barraclough, T.G., 2013. Delimiting species using single-locus data and the Generalized Mixed Yule Coalescent (GMYC) approach: a revised method and evaluation on simulated datasets. Syst. Biol. 62, 707-724. http://dx.doi.org/ 10.1093/sysbio/syt033.

Fujita, M.K., Leaché, A.D., Burbrink, F.T., McGuire, J.A., Moritz, C., 2012. Coalescentbased species delimitation in an integrative taxonomy. Trends Ecol. Evol. http:// dx.doi.org/10.1016/j.tree.2012.04.012.

Funk, W.C., Caminer, M., Ron, S.R., 2012. High levels of cryptic species diversity uncovered in Amazonian frogs. Proc. Biol. Sci. 279, 1806-1814. doi rspb.2011.1653 [pii]10.1098/rspb.2011.1653.

Gehara, M., Canedo, C., Haddad, C.F.B., Vences, M., 2013. From widespread to microendemic: molecular and acoustic analyses show that Ischnocnema guentheri (Amphibia: Brachycephalidae) is endemic to Rio de Janeiro, Brazil Conserv. Genet. 14, 973-982. http://dx.doi.org/10.1007/s10592-013-0488-5.

Gehara, M., Crawford, A.J., Orrico, V.G.D., Rodríguez, A., Lötters, S., Fouquet, A., Barrientos, L.S., Brusquetti, F., De la Riva, I., Ernst, R., Urrutia, G.G., Glaw, F., Guayasamin, J.M., Hölting, M., Jansen, M., Kok, P.J.R., Kwet, A., Lingnau, R., Lyra, M., Moravec, J., Pombal, J.P., Rojas-Runjaic, F.J.M., Schulze, A., Señaris, J.C., Solé, M., Rodrigues, M.T., Twomey, E., Haddad, C.F.B., Vences, M., Köhler, J., 2014 High levels of diversity uncovered in a widespread nominal taxon: Continental phylogeography of the Neotropical tree frog Dendropsophus minutus. PLoS One 9, e103958. http://dx.doi.org/10.1371/journal.pone.0103958.

Gehara, M., Mazzochini, G., Burbrink, F.T. PipeMaster: an R Package to build and simulate coalescent models <http://github.com/gehara/PipeMaster> (accessed in October 2016).

Girard, C., 1853. Descriptions of new species of reptiles, collected by the U.S Exploring Expedition, under the command of Capt. Charles Wilkes, U.S.N. Second part-including the species of batrachians, exotic to North America. Proc. Acad. Nat. Sci. Philadelphia 6, 420-424.

Grazziotin, F.G., Monzel, M., Echeverrigaray, S., Bonatto, S.L., 2006. Phylogeography of the Bothrops jararaca complex (Serpentes: Viperidae): past fragmentation and island colonization in the Brazilian Atlantic Forest. Mol. Ecol. 15, 39693982. http://dx.doi.org/10.1111/j.1365-294X.2006.03057.x.

Haddad, C.F.B., Toledo, L.F., Prado, C.P.A., Loebmann, D., Gasparini, J.L., Sazima, I. 2013. Guia Dos Anfíbios Da Mata Atlântica: Diversidade E Biologia. Anolis Books, São Paulo, Brasil.

Haffer, J., 1969. Speciation in Amazonian forest birds. Science 165, 131-137.

Heaney, L.R., 2007. Is a new paradigm emerging for oceanic island biogeography? J. Biogeogr. 34, 753-757. http://dx.doi.org/10.1111/j.1365-2699.2007.01692.x.

Heinicke, M.P., Duellman, W.E., Hedges, S.B., 2007. Major Caribbean and Central American frog faunas originated by ancient oceanic dispersal. Proc Natl Acad Sci USA 104, 10092-10097. http://dx.doi.org/10.1073/pnas.0611051104.

Heyer, W.R., Rand, A.S., Cruz, C.A.G., Peixoto, O.L., Nelson, C.E., 1990. Frogs of Boracéia. Arq. Zool. 31, 231-410.

Hudson, R., 2002. Ms a program for generating samples under neutral models. Bioinformatics, 337-338.
Leaché, A.D., Fujita, M.K., 2010. Bayesian species delimitation in West African forest geckos (Hemidactylus fasciatus). Proc. Biol. Sci. 277, 3071-3077. http://dx.doi. org/10.1098/rspb.2010.0662.

Librado, P., Rozas, J., 2009. DnaSP v5: a software for comprehensive analysis of DNA polymorphism data. Bioinformatics 25, 1451-1452. http://dx.doi.org/10.1093/ bioinformatics/btp187.

Lourenço-De-Moraes, R., Ferreira, R.B., Fouquet, A., Bastos, R.P., 2014. A new diminutive frog species of Adelophryne (Amphibia: Anura: Eleutherodactylidae) from the Atlantic Forest, southeastern Brazil. Zootaxa 3846, 348-360. http://dx. doi.org/10.11646/zootaxa.3846.3.2.

MacArthur, R.H., Wilson, E.O., 1967. The theory of island biogeography. Monogr. Popul. Biol. http://dx.doi.org/10.2307/1796430.

Martins, A.C.J.S., Kiefer, M.C., Siqueira, C.C., Van Sluys, M., Menezes, V.a., Rocha, C.F. D., 2010. Ecology of Ischnocnema parva (Anura: Brachycephalidae) at the Atlantic Rainforest of Serra da Concórdia, state of Rio de Janeiro, Brazil. Zoologia 27, 201-208. http://dx.doi.org/10.1590/S1984-46702010000200007.

Martins, F.D.E.M., 2011. Historical biogeography of the Brazilian Atlantic forest and the Carnaval-Moritz model of Pleistocene refugia: what do phylogeographical studies tell us? Biol. J. Linn. Soc. 104, 499-509.

Meegaskumbura, M., Bossuyt, F., Pethiyagoda, R., Manamendra-Arachchi, K., Bahir, M., Milinkovitch, M.C., Schneider, C.J., 2002. Sri Lanka: an amphibian hot spot. Science 298, 379. http://dx.doi.org/10.1126/science.298.5592.379.

Menezes, L., Canedo, C., Batalha-Filho, H., Garda, A.A., Gehara, M., Napoli, M.F., 2016. Multilocus phylogeography of the treefrog Scinax eurydice (Anura, Hylidae) reveals a Plio-Pleistocene diversification in the Atlantic Forest. PLoS One 11, e0154626. http://dx.doi.org/10.1371/journal.pone.0154626.

Miralles, A., Vences, M., 2013. New metrics for comparison of taxonomies reveal striking discrepancies among species delimitation methods in Madascincus lizards. PLoS ONE 8, e68242. http://dx.doi.org/10.1371/journal.pone.0068242.

Myers, N., Mittermeier, R.A., Mittermeier, C.G., da Fonseca, G.A., Kent, J., 2000 Biodiversity hotspots for conservation priorities. Nature 403, 853-858. http:// dx.doi.org/10.1038/35002501.

Padial, J., Miralles, A., De la Riva, I., Vences, M., 2010. The integrative future of taxonomy. Front. Zool. 7, 16. http://dx.doi.org/10.1186/1742-9994-7-16.

Padial, J.M., Grant, T., Frost, D.R., 2014. Molecular systematics of terraranas (Anura: Brachycephaloidea) with an assessment of the effects of alignment and optimality criteria. Zootaxa 3825, 1-132. http://dx.doi.org/ 10.11646/zootaxa.3825.1.1.

Pellegrino, K.C.M., Rodrigues, M.T., Waite, A.N., Morando, M., Yassuda, Y.Y., Sites, J. W., 2005. Phylogeography and species limits in the Gymnodactylus darwinii complex (Gekkonidae, Squamata): genetic structure coincides with river systems in the Brazilian Atlantic Forest. Biol. J. Linn. Soc. 85, 13-26. http://dx. doi.org/10.1111/j.1095-8312.2005.00472.x

Pfeifer, B., Wittelsburger, U., Ramos-Onsins, S.E., Lercher, M.J., 2014. PopGenome: an efficient swiss army knife for population genomic analyses in R. Mol. Biol. Evol. 31, 1929-1936. http://dx.doi.org/10.1093/molbev/msu136.

Pritchard, J.K., Stephens, M., Donnelly, P., 2000. Inference of population structure using multilocus genotype data. Genetics 155, 945-959.

Puechmaille, S.J., 2016. The program structure does not reliably recover the correct population structure when sampling is uneven: subsampling and new estimators alleviate the problem. Mol. Ecol. Resour. 16, 608-627. http://dx. doi.org/10.1111/1755-0998.12512.

R Core Team, 2016. R: A Language and Environment for Statistical Computing. R Found. Stat. Comput..

Rambaut, A., 2014. FigTree, a Graphical Viewer of Phylogenetic Trees. Inst. Evol. Biol. Univ, Edinburgh.

Rambaut, A., Drummond, A.J., 2009. Tracer v1.5 available <http://beast.bio.ed.ac.uk/ Tracer>.

Rannala, B., 2015. The art and science of species delimitation. Curr. Zool. 61, 846853. http://dx.doi.org/10.1093/czoolo/61.5.846.

Reid, N.M., Carstens, B.C., 2012. Phylogenetic estimation error can decrease the accuracy of species delimitation: a Bayesian implementation of the general mixed Yule-coalescent model. BMC Evol. Biol. 12, 196. http://dx.doi.org/ 10.1186/1471-2148-12-196.

Ribeiro, L.F., Bornschein, M.R., Belmonte-Lopes, R., Firkowski, C.R., Morato, S.A.A., Pie, M.R., 2015. Seven new microendemic species of Brachycephalus (Anura: Brachycephalidae) from southern Brazil. PeerJ 3, e1011. http://dx.doi.org/ 10.7717/peerj.1011.

Robinson, M.M., Dowsett, H.J., Chandler, M.A., 2008. Pliocene role in assessing future climate impacts. Eos 89, 501-502. http://dx.doi.org/10.1029/ 2008EO490001.

Rocha, C.F.D., Van Sluys, M., Alves, M.A.S., Bergallo, H.G., Vrcibradic, D., 2001 Estimates of forest floor litter frog communities: a comparison of two methods. Austral. Ecol. 26, 14-21. http://dx.doi.org/10.1046/j.1442-9993.2001.01073.x.

Rocha, C.F.D., Vrcibradic, D. Kiefer, M.C. Almeida-Gomes, M., Borges-Junior, V.N.T., Carneiro, P.C.F., Marra, R.V., Almeida-Santos, P., Siqueira, C.C., Goyannes-Araújo, P., Fernandes, C.G.A., Rubião, E.C.N., Van Sluys, M., 2007. A survey of the leaflitter frog assembly from an Atlantic Forest area (Reserva Ecológica de Guapiaçu) in Rio de Janeiro State, Brazil, with an estimate of frog densities. Trop. Zool. 20, 99-108

Rodríguez, A., Börner, M., Pabijan, M., Gehara, M., Haddad, C.F.B., Vences, M., 2015 Genetic divergence in tropical anurans: deeper phylogeographic structure in forest specialists and in topographically complex regions. Evol. Ecol. http://dx. doi.org/10.1007/s10682-015-9774-7.

Rowley, J.J.L., Tran, D.T.A., Frankham, G.J., Dekker, A.H., Le, D.T.T., Nguyen, T.Q., Dau, V.Q., Hoang, H.D., 2015. Undiagnosed cryptic diversity in small, microendemic 
frogs (Leptolalax) from the Central Highlands of Vietnam. PLoS One 10, e0128382. http://dx.doi.org/10.1371/journal.pone.0128382.

Salvador, C.H., Fernandez, F.A.D.S., 2008. Population dynamics and conservation status of the insular cavy Cavia intermedia (Rodentia: Caviidae). J. Mammal. 89, 721-729. http://dx.doi.org/10.1644/07-MAMM-A-0088R1.1.

Santana, D.J., Da Fonseca, E.M., De Oliveira Neves, M., De Carvalho, R.M.H., 2012. A new species of Adelophryne (Anura: Eleutherodactylidae) from the Atlantic Forest, southeastern Brazil. Salamandra 48, 187-192.

Simpson, B.B., 1979. Quaternary biogeography of the high montane regions of South America. In: Duellman, W.E. (Ed.), The South American Herpetofauna: Its Origin, Evolution, and Dispersal. Monograph of the Museum of Natural History of Kansas. University of Kansas, Swofford, pp. 157-188.

Siqueira, C.C., Vrcibradic, D., Almeida-Gomes, M., Borges-Junior, V.N.T., AlmeidaSantos, P., Almeida-Santos, M., Ariani, C.V., Guedes, D.M., Goyannes-Araújo, P., Dorigo, T.A., Van Sluys, M., Rocha, C.F.D., 2009. Density and richness of leaf litter frogs (Amphibia: Anura) of an Atlantic Rainforest area in the Serra dos Órgãos, Rio de Janeiro State, Brazil. Zoologia 26, 97-102. http://dx.doi.org/10.1590/ S1984-46702009000100015.

Smith, S.A., de Oca, A.N., Reeder, T.W., Wiens, J.J., 2007. A phylogenetic perspective on elevational species richness patterns in Middle American treefrogs: why so few species in lowland tropical rainforests? Evolution 61, 1188-1207. doi: EVO085 [pii]10.1111/j.1558-5646.2007.00085.x.

Stephens, M., Smith, N.J., Donnelly, P., 2001. A new statistical method for haplotype reconstruction from population data. Am. J. Hum. Genet. 68, 978-989. doi: S0002-9297(07)61424-4 [pii]10.1086/319501.

Stuart, B.L., Inger, R.F., Voris, H.K., 2006. High level of cryptic species diversity revealed by sympatric lineages of Southeast Asian forest frogs. Biol. Lett. 2, 470474. http://dx.doi.org/10.1098/rsbl.2006.0505.

Suguio, K., Angulo, R.J., Carvalho, A.M., Corrêa, A.M., Tomazelli, L.J., Willwock, J.A., Vital, H., 2005. Paleoníveis do mar e paleolinhas de costa. In: Souza, C.R.G., Suguio, K., Oliveira, A.M.S., Oliveira, P.E. (Eds.), Quaternário Do Brasil. Associaciação Brasileira de Estudos do Quaternário, São Paulo, São Paulo, Brasil, pp. 114-129.

Sullivan, J., Joyce, P., 2005. Model selection in phylogenetics. Annu. Rev. Ecol. Evol. Syst. 36, 445-466. http://dx.doi.org/10.1146/annurev. ecolsys.36.102003.152633.

Talavera, G., Castresana, J., 2007. Improvement of phylogenies after removing divergent and ambiguously aligned blocks from protein sequence alignments. Syst. Biol. 56, 564-577. http://dx.doi.org/10.1080/10635150701472164.

Tamura, K., Peterson, D., Peterson, N., Stecher, G., Nei, M., Kumar, S., 2011. MEGA5: molecular evolutionary genetics analysis using maximum likelihood, evolutionary distance, and maximum parsimony methods. Mol. Biol. Evol. 28, 2731-2739. http://dx.doi.org/10.1093/molbev/msr121.

Thomaz, A.T., Malabarba, L.R., Bonatto, S.L., Knowles, L.L., 2015. Testing the effect of palaeodrainages versus habitat stability on genetic divergence in riverine systems: study of a Neotropical fish of the Brazilian coastal Atlantic Forest. J. Biogeogr. 42, 2389-2401. http://dx.doi.org/10.1111/jbi.12597.

Thomé, M.T.C., Zamudio, K.R., Haddad, C.F.B., Alexandrino, J., 2014. Barriers, rather than refugia, underlie the origin of diversity in toads endemic to the Brazilian Atlantic Forest. Mol. Ecol. 23, 6152-6164. http://dx.doi.org/10.1111/mec.12986.
Tonini, J.F.R., Costa, L.P., Carnaval, A.C., 2013. Phylogeographic structure is strong in the Atlantic Forest; predictive power of correlative paleodistribution models, not always. J. Zool. Syst. Evol. Res. 51, 114-121. http://dx.doi.org/10.1111/ jzs.12014.

Tonini, J.F.R., Forlani, M.C., de Sá, R.O., 2014. A new species of Chiasmocleis (Microhylidae, Gastrophryninae) from the Atlantic Forest of Espírito Santo state, Brazil. Zookeys 132, 109-132. http://dx.doi.org/10.3897/zookeys.428.7352.

Van Sluys, M., Da Rocha, C.F., 2010. Ischnocnema parva. The IUCN Red List of Threatened Species 2010: e.T56831A11542229. doi: 10.2305/IUCN.UK.2010-2. RLTS.T56831A11542229.en. Downloaded on 27 September 2016.

Vanzolini, P.E., Williams, E.F., 1981. The vanishing refuge: a mechanism for ecogeographic speciation. Pap. Avulsos Zool. 34, 251-255. doi:citeulikearticle-id:7352881.

Vasconcelos, P.M., Becker, T.A., Renne, P.R., Brimhall, G.H., 1992. Age and duration of weathering by $40 \mathrm{~K}-40 \mathrm{Ar}$ and $40 \mathrm{Ar} / 39 \mathrm{Ar}$ analysis of potassium-manganese oxides. Science 258, 451-455. http://dx.doi.org/10.1126/science.258.5081.451.

Velo-Antón, G., Parra, J.L., Parra-Olea, G., Zamudio, K.R., 2013. Tracking climate change in a dispersal-limited species: Reduced spatial and genetic connectivity in a montane salamander. Mol. Ecol. 22, 3261-3278. http://dx.doi.org/10.1111/ mec.12310.

Vieites, D.R., Wollenberg, K.C., Andreone, F., Köhler, J., Glaw, F., Vences, M., 2009. Vast underestimation of Madagascar's biodiversity evidenced by an integrative amphibian inventory. Proc. Natl. Acad. Sci. USA 106, 8267-8272. doi:0810821106 [pii]10.1073/pnas.0810821106.

Wallace, A.R., 1852. On the monkeys of the Amazon. Proc. Zool. Soc. London, 107110.

Weisrock, D.W., Rasoloarison, R.M., Fiorentino, I., Ralison, J.M., Goodman, S.M., Kappeler, P.M., Yoder, A.D., 2010. Delimiting species without nuclear monophyly in Madagascar's mouse lemurs. PLoS One 5, e9883. http://dx.doi org/10.1371/journal.pone.0009883.

Wiens, J.J., Ackerly, D.D., Allen, A.P., Anacker, B.L., Buckley, L.B., Cornell, H.V., Damschen, E.I., Jonathan Davies, T., Grytnes, J.A., Harrison, S.P., Hawkins, B.A., Holt, R.D., McCain, C.M., Stephens, P.R., 2010. Niche conservatism as an emerging principle in ecology and conservation biology. Ecol. Lett. http://dx. doi.org/10.1111/j.1461-0248.2010.01515.x.

Wilmé, L., Goodman, S.M., Ganzhorn, J.U., 2006. Biogeographic evolution of Madagascar's microendemic biota. Science 312, 1063-1065. http://dx.doi.org/ 10.1126/science.1122806.

Wollenberg, K.C., Vieites, D.R., van der Meijden, A., Glaw, F., Cannatella, D.C., Vences, M., 2008. Patterns of endemism and species richness in Malagasy cophyline frogs support a key role of mountainous areas for speciation. Evolution 62, 1890-1907. doi:EVO420 [pii]10.1111/j.1558-5646.2008.00420.x.

Yang, Z., Rannala, B., 2010. Bayesian species delimitation using multilocus sequence data. Proc. Natl. Acad. Sci. USA 107, 9264-9269. http://dx.doi.org/10.1073/ pnas.09130221070913022107.

Zhang, C., Zhang, D.X., Zhu, T., Yang, Z., 2011. Evaluation of a Bayesian coalescent method of species delimitation. Syst. Biol. 60, 747-761. http://dx.doi.org/ 10.1093 /sysbio/syr071. 